\title{
Electrochromic Behavior of Vanadium Oxide Nanostructures Synthesized by Melt Sonoquenching
}

\author{
de Oliveira, R. S.; Oliveira, S. C.; Alves, O. C.; Semaan, F. S.; Ponzio, E. A.*
}

Rev. Virtual Quim., 2015, 7 (5), 1876-1892. Data de publicação na Web: 25 de julho de 2015

http://www.uff.br/rvq

\section{Comportamento Eletrocrômico de Nanoestruturas de Óxido de Vanádio Sintetizadas por Melt Sonoquenching}

Resumo: Neste trabalho um novo procedimento de síntese do $\mathrm{V}_{2} \mathrm{O}_{5}$ usando a combinação de dois métodos tradicionais, melt quenching e sonoquímica, chamado de melt sonoquenching foi proposto. $\mathrm{O}$ nanomaterial produzido foi caracterizado por vários métodos visando verificar características físicas e químicas, e sua possível aplicação como material eletrocrômico. Imagens de microscopia eletrônica de varredura mostraram nanofibras de óxido de vanádio com comprimentos variando de 140 a $160 \mathrm{~nm}$, e diâmetros variando de 10 a $15 \mathrm{~nm}$. Estudos de difração de raios $\mathrm{X}$ revelaram uma estrutura amorfas com espaçamento interlamelar de 13,3 Å. A composição foi estimada por TGA, sugerindo que a composição do óxido de vanádio xerogel foi de $\mathrm{V}_{2} \mathrm{O}_{5} \cdot 1.8 \mathrm{H}_{2} \mathrm{O}$. Em adição a isto, caracterizações espectroeletroquímicas mostraram uma variação de transmitância de $45 \%$ em 410 nm, com uma persistência de coloração de 91,3 \%; tempos de resposta para oxidação e redução foram de respectivamente $1 \mathrm{~s}$ e $3,5 \mathrm{~s}$. e a eficiência eletrocrômica foi de $55 \mathrm{~cm}^{2} \mathrm{C}^{-1}$ ao longo de 100 ciclos de mudanças de coloração entre azul-verde-laranja.

Palavras-chave: Eletrocromismo; eletrocrômico; $\mathrm{V}_{2} \mathrm{O}_{5}$; fusão sonoresfriamento, melt sonoquenching.

\begin{abstract}
This paper reports a new procedure for $\mathrm{V}_{2} \mathrm{O}_{5}$ synthesis using the combination of two traditional methods, melt quenching and sonochemistry, called melt sonoquenching. The resulting nanomaterial was characterized by several methods in order to verify physical and chemical characteristics, and its possible use as electrochromic electrode material. Scanning electron micrographs revealed $\mathrm{V}_{2} \mathrm{O}_{5}$ nanofibers with lengths varying from 140 to $160 \mathrm{~nm}$, and diameters varying from 10 to $15 \mathrm{~nm}, \mathrm{X}$-ray diffraction experiments pointed to an amorphous structure with an interlamellar spacing of $13.3 \AA$. Chemical composition was estimated by TGA, suggesting that the composition for such xerogel oxide was $\mathrm{V}_{2} \mathrm{O}_{5} \cdot 1.8 \mathrm{H}_{2} \mathrm{O}$. Besides these, spectroelectrochemical characterization showed a transmittance variation of $45 \%$ at $410 \mathrm{~nm}$, with coloration persistence of $91.3 \%$, response times for the oxidation and reduction were, respectively, $1 \mathrm{~s}$ and $3.5 \mathrm{~s}$, being such electrochomic efficiency of $55 \mathrm{~cm}^{2} \mathrm{C}^{-1}$ in throughout 100 cycles of color changes from blue-green-orange.
\end{abstract}

Keywords: Electrochromism; electrochromic; $\mathrm{V}_{2} \mathrm{O}_{5} ;$ melt sonoquenching.

* Universidade Federal Fluminense, Instituto de Química, Departamento de Físico-Química, Grupo de Eletroquímica e Eletroanalítica (G2E), Outeiro de São João Batista s/no, CEP 24020-141, Centro, NiteróiRJ, Brasil.

Meaponzio@vm.uff.br

DOI: 10.5935/1984-6835.20150109

Rev. Virtual Quim. |Vol 7| | No. 5| |1876-1892| 


\section{Electrochromic Behavior of Vanadium Oxide Nanostructures Synthesized by Melt Sonoquenching}

\section{Renato S. de Oliveira, ${ }^{a}$ Silvio César de Oliveira, ${ }^{b}$ Odivaldo C. Alves, ${ }^{c}$ Felipe S. Semaan, ${ }^{d}$ Eduardo A. Ponzio ${ }^{c, *}$}

${ }^{a}$ Instituto Federal de Educação, Ciência e Tecnologia do Rio de Janeiro, Campus São Gonçalo, Rua Dr. José Augusto Pereira dos Santos, s/no, CEP 24425-004, Neves, São Gonçalo-RJ, Brasil.

${ }^{\mathrm{b}}$ Universidade Federal de Mato Grosso do Sul, Instituto de Química, Cidade Universitária, CEP 79070-900, Campo Grande-MS, Brasil.

c Universidade Federal Fluminense, Instituto de Química, Departamento de Físico-Química, Grupo de Eletroquímica e Eletroanalítica (G2E), Outeiro de São João Batista s/no CEP 24020141, Centro, Niterói-RJ, Brasil.

d Universidade Federal Fluminense, Instituto de Química, Departamento de Química Analítica, Grupo de Eletroquímica e Eletroanalítica (G2E), Outeiro de São João Batista s/no CEP 24020-

141, Centro, Niterói-RJ, Brasil.

* eaponzio@vm.uff.br

Recebido em 16 de junho de 2015. Aceito para publicação em 14 de julho de 2015

1. Introduction

2. Experimental

3. Results and Discussion

4. Conclusion

\section{Introduction}

Electrochromic materials are a category of chromophores capable of undergo color changes by means of external electric stimulation; such great category of materials can be easily classified into different groups, ${ }^{1,2}$ among those, one takes special place, being the class of ion insertion materials, particularly transition metals oxides.

Electrochromic transition metal oxides have been reviewed several times, being all details covered suitably in deep and range by literature, in many details in books ${ }^{3,4}$ and reviews. ${ }^{5,6}$ These transition metal oxides may be classified according to the color change associated to the insertion/extraction of charge as anodic or cathodic oxides.

Oxides derived from $\mathrm{W}, \mathrm{Mo}, \mathrm{Nb}$, and $\mathrm{Ti}$, have been referred as cathodic electrochromic materials, being the color changes related to charge insertions while, on the other hand, oxides from $\mathrm{Ru}, \mathrm{Rh}, \mathrm{Cr}$, $\mathrm{Co}, \mathrm{Fe}, \mathrm{Mn}$, Ir, and $\mathrm{Ni}$ have been called anodic electrochromic materials, since color changes occur as consequence of charge extractions; 
according to the above given definition it is clearly noted that vanadium oxide is exception, since it presents an intermediate nature, exhibiting cathodic and anodic behaviors (presenting different colors) in different wavelength ranges and potentials.
$\mathrm{V}_{2} \mathrm{O}_{5}$ films can be promptly and reversibly converted from yellow to green by the addition of ions and even electrons, to form vanadium bronze $\left(\mathrm{M}_{\mathrm{x}} \mathrm{V}_{2} \mathrm{O}_{5}\right)$, according to the following reaction of insertion/extraction (Eq. $1)$.

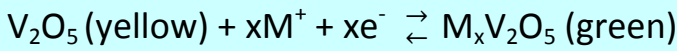

$$
\begin{aligned}
& \mathrm{M}=\mathrm{H}, \mathrm{Li}, \mathrm{Na} \text { or } \mathrm{K} \text { ions }
\end{aligned}
$$

Vanadium exists in many different states of oxidation (and, thus, oxide forms), di-, sesqui-, and pentoxides $\left(\mathrm{VO}_{2}, \mathrm{~V}_{2} \mathrm{O}_{3}\right.$, and $\mathrm{V}_{2} \mathrm{O}_{5}$ ). They have been processed in thin film forms and applied as optical/electrical devices. In this context, vanadium oxide $\left(\mathrm{V}_{2} \mathrm{O}_{5}\right)$ stands for an special case: presenting wide band gap and acting as n-type semiconductor material, such oxide form has been widely investigated due to its interesting electrochemical performance, possibilities of use in lithium secondary batteries, ${ }^{7,8}$ and thermochromic devices. ${ }^{9,10}$

Electrochemical studies have shown that the performance of vanadium oxide films is directly related to their crystallinity, morphology, disorder degree, stoichiometry, and other parameters related to the methods and conditions of the synthesis. In particular, significant differences are reported, being them related to the optical transmittance of amorphous and crystalline vanadium oxide thin film electrodes under lithium electrochemical intercalation, as a consequence of external perturbation (external potential). ${ }^{11}$ Amorphous phase is characterized by a lamellar structure which directly dependents on the amount of water present and heat treatment to which such material is subjected. ${ }^{12-14}$ The lamellar distance plays an important role in the intercalation/mobility of ions for charge compensation during the redox processes.

Vanadium oxide can be produced by various techniques, among them we can highlight sol-gel method (method alcoxide), spray pyrolysis, magnetron sputtering, pulsed laser and/or chemical vapor deposition, electrospinning, sonochemistry, melt quenching, among others. ${ }^{15-22}$ The synthetic paths' choice can be oriented as a function of future application, thus, such oxide can be deposited as thin films onto various substrates such as glass electrodes coated by a thin layer of ITO (tin oxide doped with indium) or even FTO (tin oxide doped with fluorine), such oxide.

Sol-gel strategy (by alcoxide) is widely used for vanadium oxide production, although some disadvantages can be easily noted, such as the use of expensive toxic precursors, long processing times and low reproducibility of properties of the final materials, only achieved through a careful control of the experimental conditions of synthesis. ${ }^{23}$ Synthesis by sputtering also has many drawbacks, such as the use of high cost equipment, the quite low deposition rate of some materials, degradation of raw materials under high energy and pressure exposures.

Sonochemical methods have been successfully applied to the preparation of $\mathrm{V}_{2} \mathrm{O}_{5}{ }^{24,25}$ Sonochemistry rises its success in creating nanostructured materials principally from acoustic cavitation; the formation, growth, and implosive collapse of bubbles in a liquid. ${ }^{26-28}$ On the other hand, sonochemical synthesis of different oxides can produce different crystalline structures. For example, Ohayon and $\mathrm{col}^{29}$ synthesized vanadium oxide by this method, reaching mixed crystalline phases, being then necessary to carry out a heat treatment after synthesis to obtain a single-phase.

The synthesis of $\mathrm{V}_{2} \mathrm{O}_{5}$ by melt-quenching, 
as reported by some authors, ${ }^{22,30-34}$ stands out due to advantages such as easy implementation and use of simpler/ cheaper equipment. Large quantities of these gels are today prepared this way for industrial purposes.

In this paper, we present a fast and easy route to produce $\mathrm{V}_{2} \mathrm{O}_{5}$ nanowires by mixing two techniques, melt-quenching, and sonochemistry; this result in a novel method called melt sonoquenching. ${ }^{35}$ This novel synthetic route has some special advantages: low-cost, large-scale production and good electrochromic response.

\section{Experimental}

Amorphous vanadium pentoxide was prepared by combining melt quenching and sonochemical techniques. Suitable amounts of $\mathrm{NH}_{4} \mathrm{VO}_{3}(5.0 \mathrm{~g}, 99 \%$ pure, VETEC) were melted at $800{ }^{\circ} \mathrm{C}$ in a small ceramic crucible during one hour, being then quenched by pouring the melted oxide into a Pyrex crucible with $50 \mathrm{~mL}$ of water, at $25^{\circ} \mathrm{C}$, placed into an active ultrasound bath (UNIQUE USC1400, $40 \mathrm{kHz}$ e $120 \mathrm{~W}$ ). A dark red gel was obtained, being then suitably diluted providing this way a colloidal solution. The quenched material was kept in a sealed tube for 7 days. The sample was separated into two aliquots. One sample was subject to thermal treatment in a furnace at $110{ }^{\circ} \mathrm{C}$ (under air exposure) for 24 hours, and used for characterization by $x$-ray difractometry (Bruker-AXS-D8 advanced X-ray diffraction, $40 \mathrm{kV} / 40 \mathrm{~mA}$, using monochromatizated $\mathrm{Cu}$ ka radiation - $1.54056 \AA ̊$ ), thermogravimetric analysis (TGA), and Infrared spectroscopy (FTIR reflectance was recorded in the $400-4000$ $\mathrm{cm}^{-1}$ range using a double beam spectrometer Varian 660).

Besides these, further characterization procedures were carried out by electron microscopy (MEV) and electrochemical analysis using films made by using the second separated aliquot. Fluorine doped tin oxide
(FTO) (FlexiTec Organic Electronic $10 \leq \mathrm{R} \leq 20$ $\Omega \mathrm{cm}^{-1}, 42 \mathrm{~mm}^{2}$ ) substrates were coated by gel-derived thin films, solvent was dried at $110^{\circ} \mathrm{C}$ in an air exposed furnace. Electron paramagnetic resonance (EPR) spectra were obtained at room temperature $\left(25^{\circ} \mathrm{C}\right)$ using a esp300e Bruker spectrometer operating at about $9.5 \mathrm{GHz}$ (X band). Field emission scanning electron microscopy (FESEM) images were taken using a FEG Jeol jsm6701f. Thermogravimetric analyzes (TGA), and differential thermal analyses (DTA) were simultaneously carried out using Shimadzu DTG-60 TGA-DTA. The fine powdered samples were placed into an opened aluminum crucibles, data were taken under $10{ }^{\circ} \mathrm{C} \mathrm{min}^{-1}$ heat rate, from room temperature until $550{ }^{\circ} \mathrm{C}$, under dynamic nitrogen atmosphere $\left(50 \mathrm{~mL} \mathrm{~min}{ }^{-1}\right)$.

Electrochemical experiments were developed by using a $\mu$ Autolab III potentiostat/galvanostat, a three electrode cell was designed and prepared using as counter electrode a platinum sheet with an area of $4.5 \mathrm{~cm}^{2}$ was used, as a quasireference electrode a $\mathrm{Ag}$ wire and, as working electrode thin films of $\mathrm{V}_{2} \mathrm{O}_{5}$ supported onto FTO substrates $\left(42 \mathrm{~mm}^{2}\right)$. As supporting electrolyte solutions were prepared by adding $0.5 \mathrm{~mol} \mathrm{~L}^{-1} \quad \mathrm{LiClO}_{4}$ (Aldrich) in pure acetonitrile (HPLC grade). A typical spectrophotometer cuvette was used as an electrochemical cell. UV-vis experiments were done by applying a Varian UV-Vis 50 spectrophotometer, in which the electrochemical cell was placed, adapting the working electrode through the optical path of the equipment.

\section{Results and Discussion}

In this study the $\mathrm{V}_{2} \mathrm{O}_{5}$ was obtained using the combination of two techniques, melt quenching and ultrasound exposure. Such preparation method revealed promising results strongly validating them as an alternative route for the synthesis of 
nanostructures overcoming some conventional methods in terms of costs and large-scale production potential. The results obtained revealed that the ultrasound has a very important role.

The melt quenching synthesis used in the production of vanadium oxide is based on heating the vanadium oxide in temperatures above its melting point with subsequent abrupt cooling to room temperature $\left(25^{\circ} \mathrm{C}\right)$. The heating at $800{ }^{\circ} \mathrm{C}$ of the $\mathrm{NH}_{4} \mathrm{VO}_{3}$ for one hour was sufficient to allow the precursor to undergo total decomposition, forming vanadium pentoxide, according to reaction (Eq. 2). The melting point of the vanadium oxide occurs at a temperature of $670{ }^{\circ} \mathrm{C}$, forming vanadium oxide in liquid state, according to reaction (Eq. 3). By putting abruptly the liquid vanadium oxide into water under ultrasonic bath at room temperature, a gel is immediately formed $\left(\mathrm{V}_{2} \mathrm{O}_{5} \cdot \mathrm{nH}_{2} \mathrm{O}\right.$ xerogel) with a dark orange color, according to reaction (Eq. 4).
The influence of ultrasonic radiation over heterogeneous media is complex since it may involve several chemical and/or physical processes, such as the production of reactive free radicals, shock waves, mass transfer, microstreaming, microjets, enormous local temperatures and pressures, mixing, etc., all associated with the process of cavitation. ${ }^{36}$

Currently, the influence of ultrasound waves and the mechanism of formation of the $\mathrm{V}_{2} \mathrm{O}_{5}$ are still under investigation. The reactions were induced by low frequency/high intensity sound waves, resulting in a more violent cavitation bubble, generating a higher localized temperature and pressure, what could, possibly, improve the formation of nanostructures of $\mathrm{V}_{2} \mathrm{O}_{5}$.

Apparently, physical effects such as microstreaming, microstreamers, microjets, and shock waves cause turbulent fluid movements and provoke, during the cooling process, a unique crystal growth. The fast uniform cooling process creates a kinetic condition unfavorable to the occurrence of recrystallization but favorable to produced nanowires. The microstreaming in association to the microjets results in desaggregation of particles, erosion on particle's surface and prevent the particle growth.

Radical species may react with the material surface; however, due to the short treatment periods in this study, radicals were not expected to have an effect on the system.

Figure 1 presents the results of the X-ray diffractometry (XRD), in which the XRD pattern reveals the formation of an amorphous material. The presence of diffraction peak in $2 \theta=6.6^{\circ}$ referring to the diffraction plan (001) corresponds to an interllamelar spacing of approximately 13.3 $\AA$, there is still another peak in $2 \theta=25.5^{\circ}$ referring to diffraction plan (003). These results are in accordance to those found in literature for $\mathrm{V}_{2} \mathrm{O}_{5} \cdot \mathrm{nH}_{2} \mathrm{O}$ xerogel. ${ }^{12}$ 


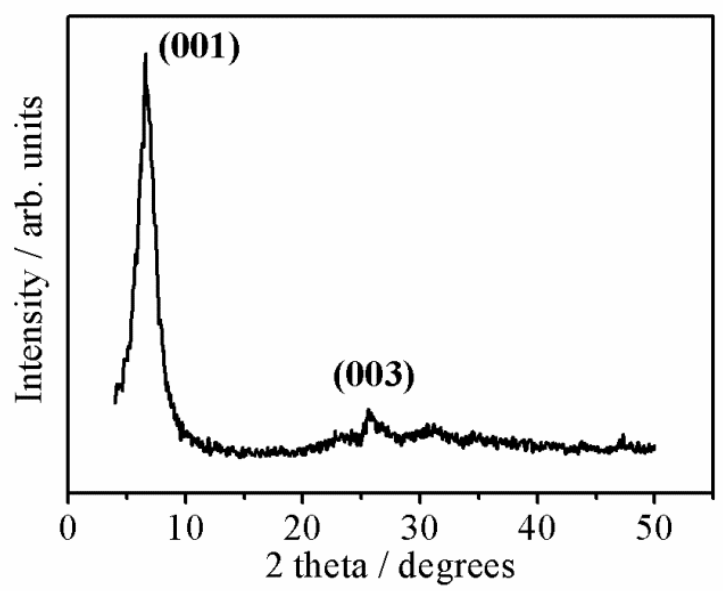

Figure 1. X-ray diffractometry (XRD) pattern of $\mathrm{V}_{2} \mathrm{O}_{5}$ xerogel

The interllamelar spacing of $13.3 \AA$ corresponds to the distance between the vanadium oxide lamellas separated by water molecules. With the intention of verifying the relation between the interllamelar spacing and the quantity of intercalated water, measurements were made of TGA-DTA, according to Figure 2 .

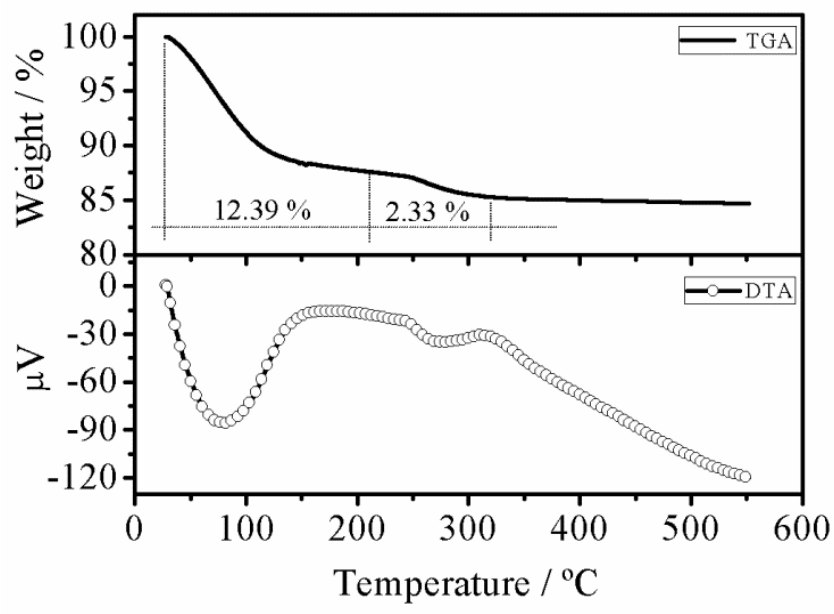

Figure 2. TGA-DTA measurements of $\mathrm{V}_{2} \mathrm{O}_{5}$ xerogel

Thermogravimetric analysis showed in Figure 2(a) presents two well defined stages of mass loss. The first, with a mass loss of $12.39 \%$, is attributed to the loss of water adsorbed between the lamellas of vanadium oxide extending up to $210{ }^{\circ} \mathrm{C}$; the second stage, on the other hand, had lower intensity ( $2.33 \%$ of mass loss), and could be observed between 210 and $320{ }^{\circ} \mathrm{C}$, such event is possibly related to the release of water molecules coordinated to the vanadyl groups, and molecules present in the lamella plan. ${ }^{37}$ Considering that the initial mass of the sample was $11.3617 \mathrm{mg}$, by a simple mathematical relation, it was determined that the mass of water present in the $\mathrm{V}_{2} \mathrm{O}_{5}$ dry gel was $1.6724 \mathrm{mg}$, that is, $1.8 \mathrm{~mol}$ of water per mol of $\mathrm{V}_{2} \mathrm{O}_{5}$, therefore the most 
probable formula of hydrated vanadium oxide is $\mathrm{V}_{2} \mathrm{O}_{5} \cdot 1.8 \mathrm{H}_{2} \mathrm{O}$.

The formula $\mathrm{V}_{2} \mathrm{O}_{5} \cdot 1.8 \mathrm{H}_{2} \mathrm{O}$ is directly related with the interplanar distance of 13.3 $\AA$. Comparing the data of the hydrated vanadium oxide structure and the interllamelar spacing, it can be noted that they are coherent with the data found in literature according to Table 1.

Table 1. Composition and interlayer distance (d) of $\mathrm{V}_{2} \mathrm{O}_{5} \cdot \mathrm{nH}_{2} \mathrm{O}$ according to literature

\begin{tabular}{lcl}
\hline Composition & $\mathbf{d}(\AA)$ & Literature \\
\hline $\mathrm{V}_{2} \mathrm{O}_{5} \cdot 0,5 \mathrm{H}_{2} \mathrm{O}$ & 8,7 & Baddour et al. ${ }^{38}$ \\
$\mathrm{~V}_{2} \mathrm{O}_{5} \cdot 1,6 \mathrm{H}_{2} \mathrm{O}$ & 11,6 & Zakharova et al. ${ }^{13}$ \\
$\mathrm{~V}_{2} \mathrm{O}_{5} \cdot \mathrm{nH}_{2} \mathrm{O}(\mathrm{n}=1,6-1,8)$ & 11,8 & Kang et al. ${ }^{14}$ \\
$\mathrm{~V}_{2} \mathrm{O}_{5} \cdot 1,9 \mathrm{H}_{2} \mathrm{O}$ & 11,8 & Oliveira et al. ${ }^{37}$ \\
\hline
\end{tabular}

It was also noted that as the quantity of intercalated water increases, the interllamelar spacing increases; and that the values of interplanar distance for similar structure is viable, but oscillates near the same value, which is probably related to different drying times of the synthesized materials, and also due to the different synthesis methods applied.
The morphology of the vanadium oxide was analyzed using a field emission scanning electron microscopy (FEG-SEM), according to Figure 3 . The presence of a nanofibrous structure can be seen composed by agglomerates of fibers of $\mathrm{V}_{2} \mathrm{O}_{5}$ with lengths varying from 140 to $160 \mathrm{~nm}$ and diameters varying from 10 to $15 \mathrm{~nm}$.

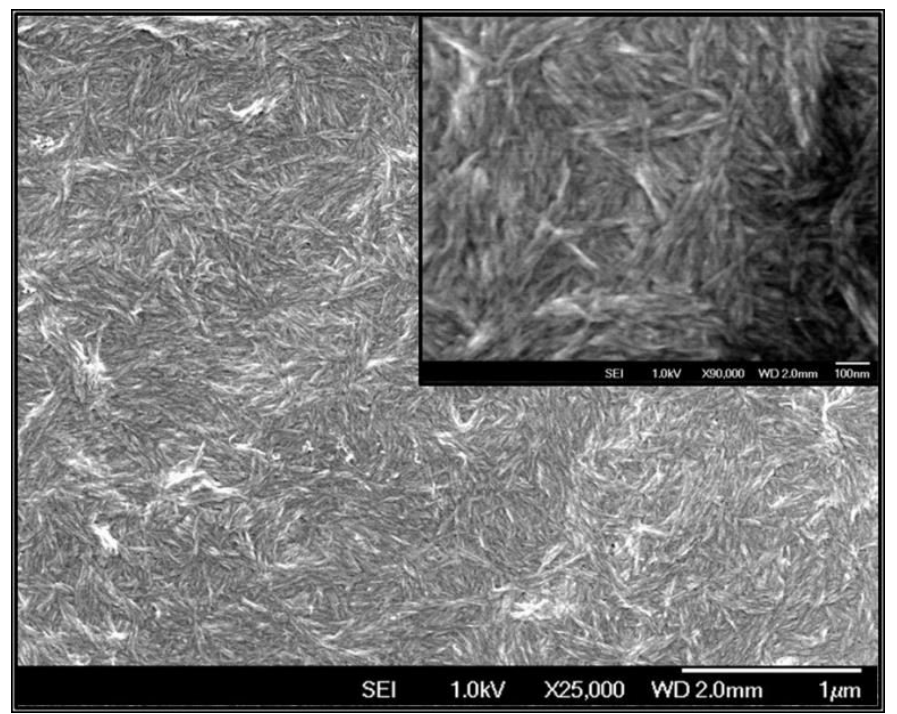

Figure 3. Field emission scanning electron microscopy (FEG-SEM) of $\mathrm{V}_{2} \mathrm{O}_{5}$ nanowires ( $\mathrm{x} 25.000$ ). Inside micrograph of $\mathrm{V}_{2} \mathrm{O}_{5}$ with magnification of $\times 90.000$

Several articles have reported the synthesis of $\mathrm{V}_{2} \mathrm{O}_{5}$ by thermal decomposition of $\mathrm{NH}_{4} \mathrm{VO}_{3}$ and the melting quenching of $\mathrm{V}_{2} \mathrm{O}_{5}$. When $\mathrm{V}_{2} \mathrm{O}_{5}$ is prepared by thermal decomposition of $\mathrm{NH}_{4} \mathrm{VO}_{3}$ the synthesis results in powdered materials with particle size of few micrometers. ${ }^{39-43}$ 
For example, Adhikary and col. ${ }^{30}$ obtained $\mathrm{V}_{2} \mathrm{O}_{5}$ fibers from a melt quenching with a size from 2 to $3 \mathrm{~mm}$ in length and $0.1 \mathrm{~mm}$ in width; Cocciantelli and col. $^{34}$ observed different sizes varying from 2 up to 50 um.

For other hand, Livage and col. ${ }^{42}$ produced amorphous $\mathrm{V}_{2} \mathrm{O}_{5}$ by the splat cooling of the molten oxide and this oxide made of crosslinked fibers about some micrometer long.

Sizes of particles seen in the mixed synthesis is related to the fact that in the melt quenching synthesis the process of fast cooling. The use of the ultrasonic bath in the synthesis of $\mathrm{V}_{2} \mathrm{O}_{5}$ provides a higher homogenization of the medium and contributes to the increase of cooling rate, which causes a decrease in the growth of crystals. Therefore, this type of synthesis provides the formation of stable nanoparticles.

The hydrated vanadium oxide was also characterized by infrared spectroscopy (Figure 4), in which were observed a band at $998 \mathrm{~cm}^{-1}$ assigned to the distention of groups $\mathrm{V}=\mathrm{O}$ not equivalent, $\mathrm{a}$ band at $798 \mathrm{~cm}^{-1}$ related to the distention of connection $\mathrm{V}-\mathrm{O}$, and $a$ band at $532 \mathrm{~cm}^{-1}$ assigned to the asymmetric distention of $\mathrm{V}-\mathrm{O}-\mathrm{V}$, all of these designations are in accordance to the data found in literature. ${ }^{13,44}$

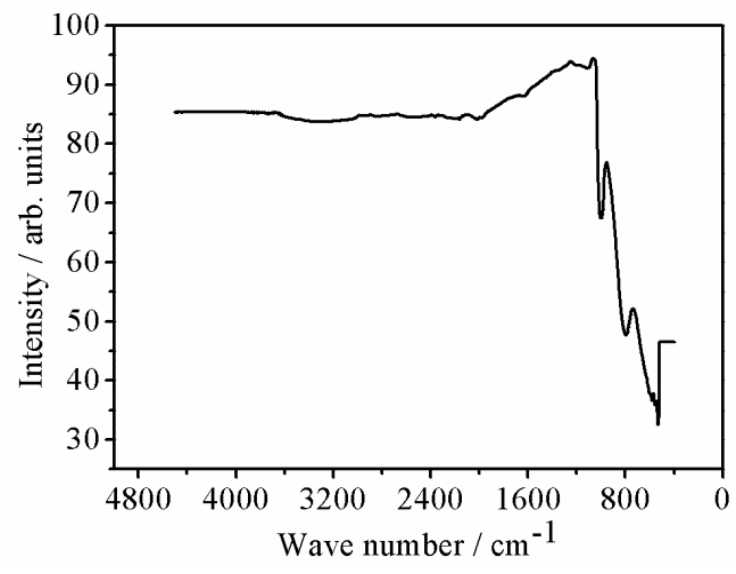

Figure 4. FT-IR spectrum of $\mathrm{V}_{2} \mathrm{O}_{5}$ xerogel

Another way to characterize the materials is using electron paramagnetic resonance (EPR) spectroscopy. As shown in Figure 5 the EPR spectrum recorded at room temperature can be fitted by the sum of two components indicating that the ions $\mathrm{V}^{4+}$ is not distributed homogeneously, with regions of different ionic densities.

The component $A$ at $g=1.97$ is broad (line with of $100 \mathrm{G}$ ) and structure less displaying a symmetric line shape. The absence of hyperfine interaction indicates strong interaction between the ions $\mathrm{V}^{4+} .{ }^{45,46}$
The second component shows the typical liquid-like isotropic spectrum, consisting of eight lines due to hyperfine interaction of the unpaired electron with ${ }^{51} \mathrm{~V}$ whose natural abundance is $99.5 \%$ and nuclear spin is $\mathrm{I}=7 / 2$

The simulations using easy-spin program ${ }^{47}$ yield g-values and hyperfine components $g_{0}=1,97$ and $A_{0}=116 G$ that seemed to be in good agreement with those obtained for the high temperature liquid-like spectrum of vanadium pentoxide gel. 
de Oliveira, R. S. et al.

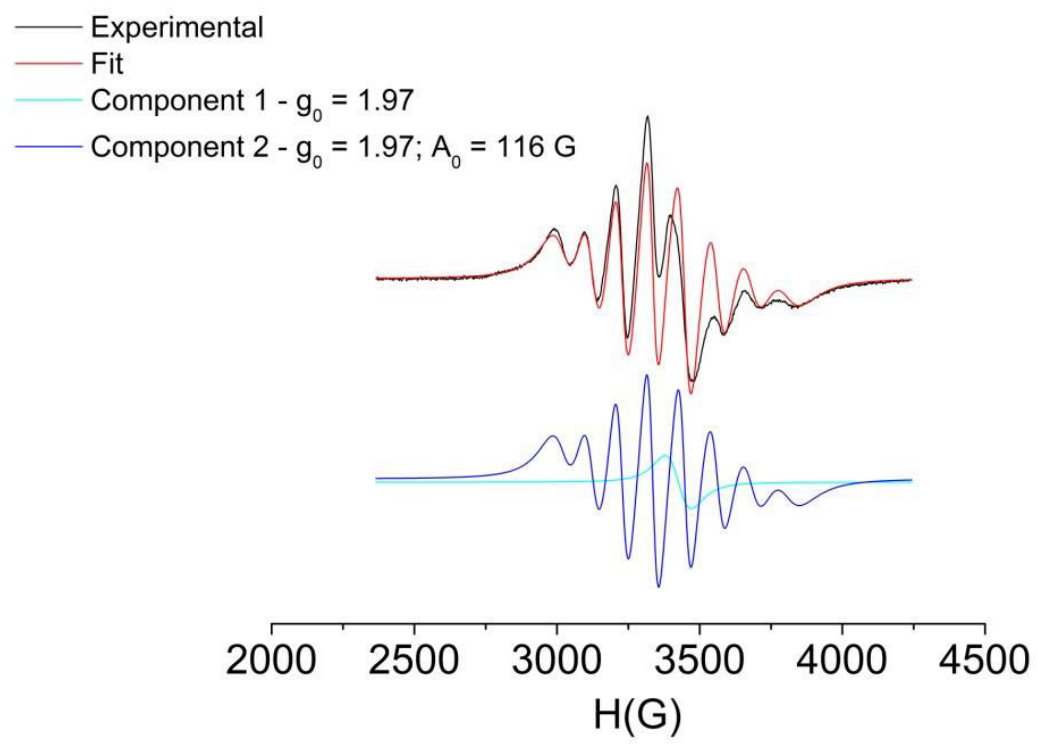

Figure 5. Electron paramagnetic resonance (EPR) spectroscopy of $\mathrm{V}_{2} \mathrm{O}_{5}$ xerogel

This isotropic spectrum confirms the formation of an amorphous material obtained by XRD and is due to Brownian motion of paramagnetic species on the surface. This molecular motion is only possible due to the presence intercalation water that provides enough interlayer space for vanadyl ions to move.

Spectroelectrochemical characterization in situ of the synthesized vanadium oxide was made in order to verify their potentialities for application in electrochromic electrodes. A fundamental characteristic for the application in electrodes of electrochromic devices is the reversibility in the redox and concomitant process of intercalation/deintercalation of ions in the electrode's structure.

The results of cyclic voltammetry experiments for $\mathrm{V}_{2} \mathrm{O}_{5}$, Figure $6(\mathrm{a})$ shows with the applied voltage was between -0.6 and 1.2 $\mathrm{V}$ relative to $\mathrm{Ag}$ quasi-reference electrode with a scanning rate of $5 \mathrm{mV} \mathrm{s}^{-1}$ and Pt was used as a counter electrode in electrolyte (0.5 mol L ${ }^{-1} \mathrm{LiClO}_{4} /$ acetonitrile), revealed a reversibility of the redox processes. In the direct sweep, when analyzing the chart in
Figure 6(a) it is possible to observe the presence of two oxidation waves, one at 0.18 $\mathrm{V}$ and another at $0.60 \mathrm{~V}$. The first is due to the oxidation of part of the vanadium sites $(+4)$ to vanadium $(+5)$. The second oxidation wave corresponds to the oxidation in the remaining vanadium sites $(+4)$ for the state of oxidation +5 . During the inverse sweep, it is also possible to observe the occurrence of two peaks of reduction, one at $0.42 \mathrm{~V}$ related to the reduction of part of $\mathrm{V}(+5)$ to $\mathrm{V}(+4)$ and another at $-0.27 \mathrm{~V}$ related to the reduction of other vanadium sites $(+4)$.

Figure $6(\mathrm{~b})$ shows two UV-Vis spectra obtained with the chronoamperometry technique, in which we applied the extremes potentials used in the cyclic voltammetry technique. The conjoint analysis of the cyclic voltammetry (Figure 6(a)) with the UV-Vis spectra (Figure 6(b)) shows that at the end of the oxidation stage of the material, at $1.2 \mathrm{~V}$, the same has an absorption band at $378 \mathrm{~nm}$. It was also observed that in the beginning of the anodic sweep at $-0.6 \mathrm{~V}$, an accentuated decrease of the band situated at $378 \mathrm{~nm}$ and the appearance of a lower intensity band at $748 \mathrm{~nm}$. 


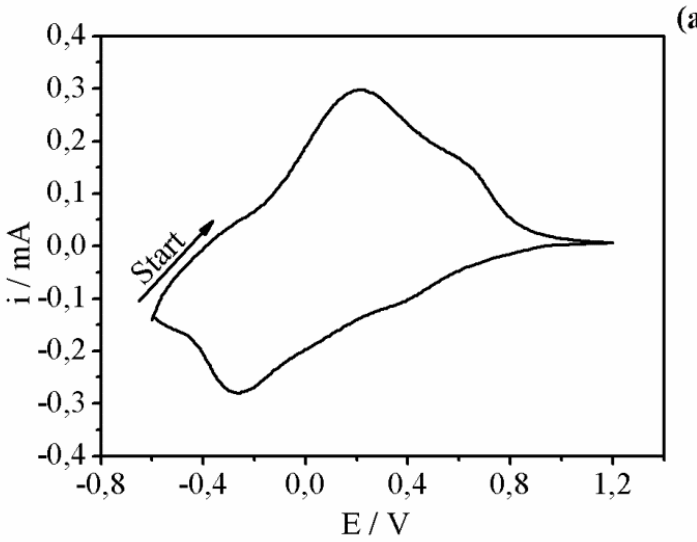

Figure 6. Cyclic voltammetry experiments in (a) and UV-Vis spectra in (b) for $\mathrm{V}_{2} \mathrm{O}_{5}$ produced

When observing if the behavior of the absorption spectra of the material due to the applied potential, imposing $1.2 \mathrm{~V}$, only one band is seen with the maximum absorption at $378 \mathrm{~mm}$. This band corresponds to a transition by load transference for the $\mathrm{V}(+5)$, in which according to Ryczkowsky ${ }^{48}$ the load transference of the binder to the metal (LMTC) occur in regions from 200 to $550 \mathrm{~nm}$. In another study, Chary and col.. ${ }^{49}$ indicated that the band at approximately $380 \mathrm{~nm}$ refers to the transition that occurs from the binder to the metal (LMTC) typical of ions $V(+5)$ coordinated by five oxygen atoms in the shape of a square-based pyramid. When applying $-0.6 \mathrm{~V}$, the spectrum obtained show

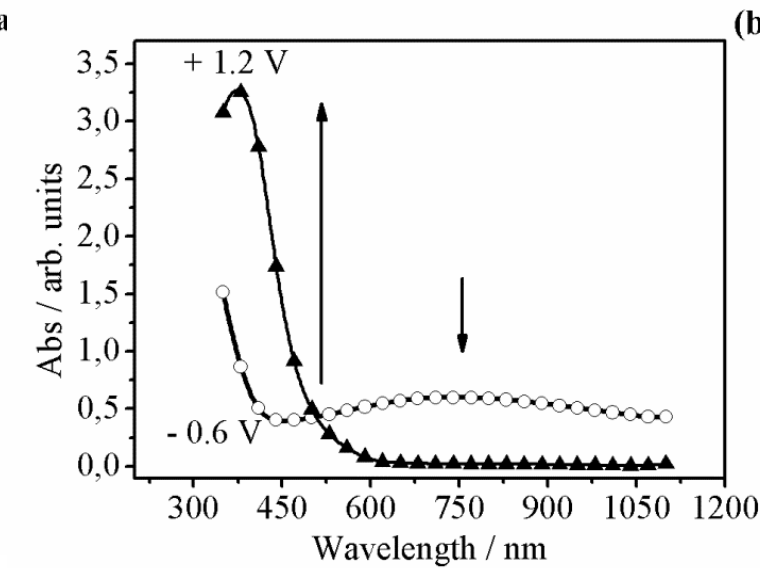

a wide band at $748 \mathrm{~nm}$, which corresponds to transition $d-d$ that occurs for $V(+4)$ in the region 400-1000 $\mathrm{nm}$ and has a very low intensity when compared to the LMTC transitions.

The wavelength in which the $\mathrm{V}_{2} \mathrm{O}_{5}$ has the highest absorbance variation (Figure $6(\mathrm{~b})$ ) is $410 \mathrm{~nm}$, thus, we made a follow-up of the change in color in the $\mathrm{V}_{2} \mathrm{O}_{5}$ through cyclic voltammetry experiments in this length of specific wave. Figure 7 presents the results of the measurements in situ of cyclic voltammetry and transmittance variation in function of the potential in the wavelength of $410 \mathrm{~nm}$ for the $\mathrm{V}_{2} \mathrm{O}_{5}$.

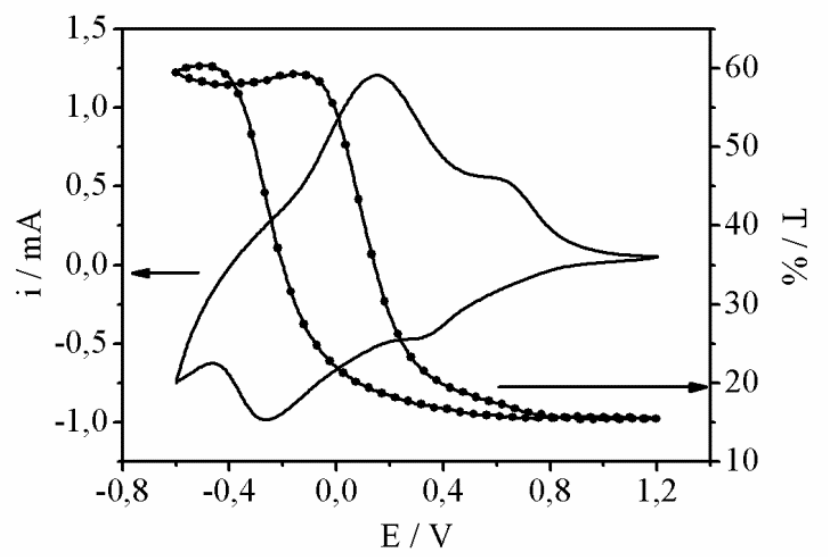

Figure 7. Cyclic voltammetry and transmittance variation in situ in function of the potential in the wavelength of $410 \mathrm{~nm}$ for the $\mathrm{V}_{2} \mathrm{O}_{5}$ 
Transmittance variation of circa $45 \%$ (410 $\mathrm{nm}$ ) has been noted. This indicates that the material modulates its color in function of a difference of potential applied, allowing and encouraging its use for application in electrochromic devices.

With the intention of proving the existence of a direct cause/effect relationship between applied potential and variations in optic properties of $\mathrm{V}_{2} \mathrm{O}_{5}$ at $410 \mathrm{~nm}$, the derivative of absorbance variation related to time in function of the potential range was calculated. Figure 8 shows a cyclic voltammogram along with the absorbance derivative in function of time.

The methods came from the principle that in electrochemical processes the absorbance variation are proportional to the electric charges involved, therefore, the maximums and minimums obtained by the absorbance differentiation in relation to time $(\mathrm{dA} / \mathrm{dt})$ must correspond to the oxidation-reduction peaks seen in cyclic voltammogram, except if the capacitive current does not show in the optic measurement. In wavelength values in which curves $\mathrm{dA} / \mathrm{dt}$ and $\mathrm{i}$ vs $\mathrm{E}$ coincide, species involved in the redox reactions are responsible for the color alteration in the studied wavelength.

Figure 8 shows that the potential peaks of anodic and cathodic currents of the voltammograms coincide with the maximum and minimum of the $d A / d t$ curves for the measurements made at $410 \mathrm{~nm}$, which indicates that the transference of electrons occurred in these processes generating, this way, color changes.

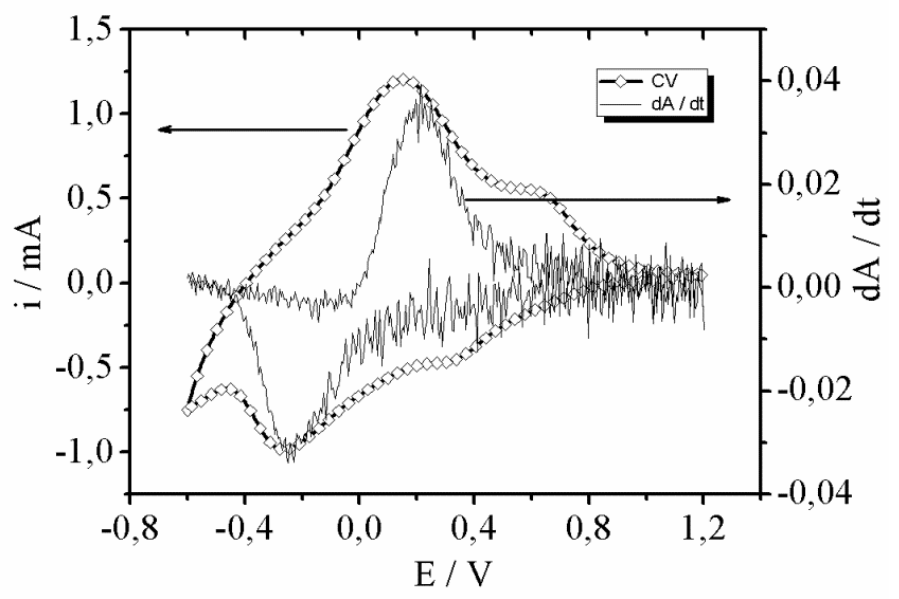

Figure 8. Cyclic voltammogram and absorbance differentiation in relation to time $(\mathrm{dA} / \mathrm{dt}$ in 410 $\mathrm{nm}$ ) in situ for the $\mathrm{V}_{2} \mathrm{O}_{5}$ produced

The absorbance derivative as function of time showed that for an infinitesimal variation of absorbance in potential range from -0.6 to $1.2 \mathrm{~V}$, it is possible to observe that oxidizing the material at approximately $0.2 \mathrm{~V}$ causes a decrease in transmittance. This indicates that the material is absorbing the wavelength radiation of $410 \mathrm{~nm}$, taking a positive variation of $\mathrm{dA} / \mathrm{dt}$ soon after completing oxidation according to Figure 8 . Under a potential of approximately $-0.35 \mathrm{~V}$, during the reduction stage, we noticed an increase in transmittance favoring the passage of wavelength radiation of $410 \mathrm{~nm}$. In this moment, there is a negative variation of $\mathrm{dA} / \mathrm{dt}$. Considering this, it can be verified that the process of change in spectrum is directly related to the electrochemical process of oxidation and reduction.

Aiming to assess the behavior of the electrode in several cycles of oxidation and reduction, followed by the absorbance variations during these processes, 
chronoamperometric analysis were carried out monitoring optic density variations in situ. Using the wavelength of $410 \mathrm{~nm}$, successive programmed cycles (potentials of $0.6 \mathrm{~V}$ for 10 seconds, and $1.2 \mathrm{~V}$ for the same duration) were applied. Changes of color from blue to orange were monitored as a function of cycling time. Figure 9 (a) and (b) show, after 100 cycles of color changes the material's transmittance variations keep a practically constant behavior, around $91.3 \%$ of the initial variation. It can also be observed that application time intervals of the used potentials (10 seconds) were suitable and sufficient to promote the color changes among blue, green and orange.
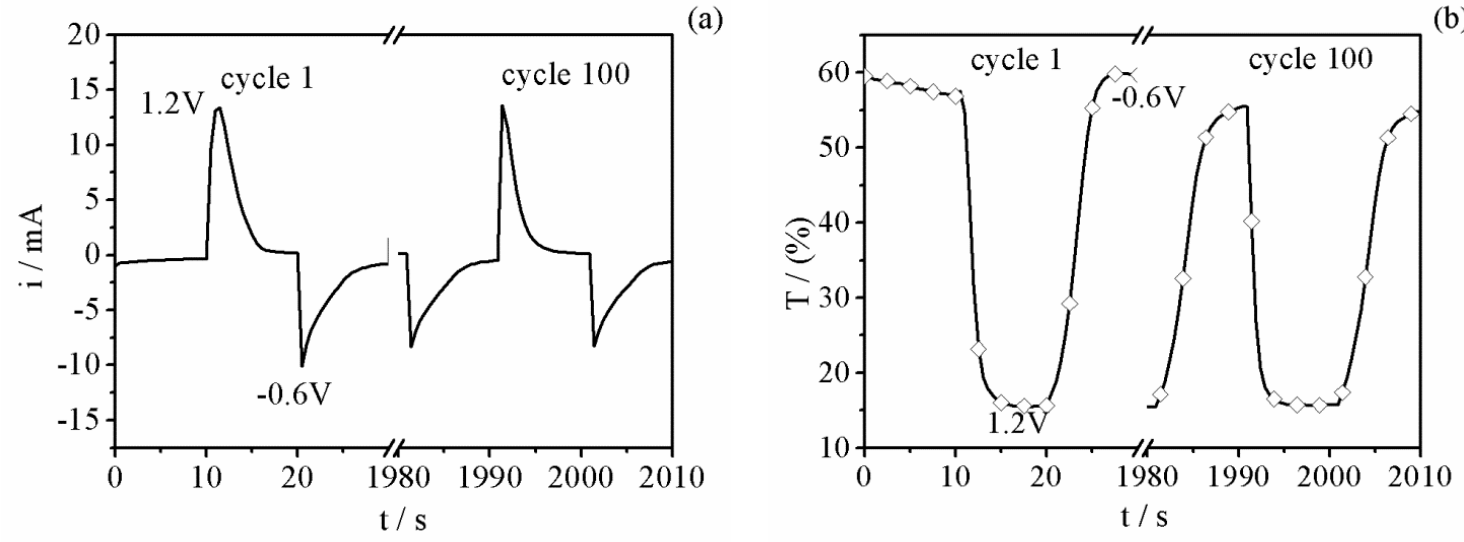

Figure 9. Chronoamperometric analysis was with in situ optic density variation using the wavelength of $410 \mathrm{~nm}$

With the data obtained in Figure 9, the electrochromic efficiencies and the response times were calculated for the oxidation and reduction of $\mathrm{V}_{2} \mathrm{O}_{5}$.

The electrochromic efficiency relates the absorbance variation $(\Delta A)$ with the inserted charge per unit of film area $(Q)$ in the system. It is calculated using the integration of current curve versus time (figure 9(a)). The electrochromic efficiency $(n)$ is defined according to the Equation 5 below.

$$
\eta=\Delta \mathrm{A} / \mathrm{Q}
$$

We have noticed that for the reduction as well as the oxidation of the vanadium oxide as the 100 cycles are made, the electrochromic efficiency of $\mathrm{V}_{2} \mathrm{O}_{5}$ kept at 55 $\mathrm{cm}^{2} \mathrm{C}^{-1}(410 \mathrm{~nm})$.
The electrochromic response time $(t)$ is the necessary time for the material to change color, although there is not specific criterion to determine this response time, it could have been obtained by the total transmittance variation (or absorbance) or by a fraction of this. ${ }^{50}$ In this study, the response time calculation is defined as the necessary time from the beginning of the pulse until it reaches $50 \%$ of the total transmittance or absorbance variation of each pulse. The response times are presented in Figure 10.

In analyzing the response times necessary for the oxidation and reduction of the material a significant difference between them can be noticed. The response time of the reduction (around 3.5 seconds) is always higher than the response time for the oxidation (less than 1 second) throughout the 100 cycles, indicating that the $\mathrm{V}_{2} \mathrm{O}_{5}$ film takes a time approximately 3.5 times longer to become blue than to become orange. 
de Oliveira, R. S. et al.

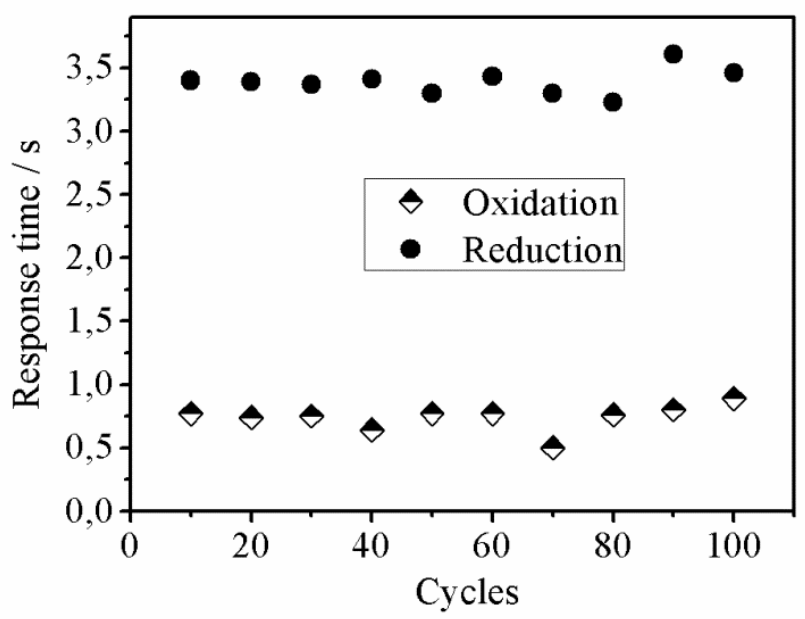

Figure 10. Electrochromic response time of $\mathrm{V}_{2} \mathrm{O}_{5}$

Another important parameter is the coulombic efficiency, given by the oxidation/reduction charges ratio, it was noticed for the first cycle of oxidationreduction the coulombic efficiency was 1.27 showing that during the first cycle the process of oxidation was more effective than the reduction of the material and consequently, the de-insertion of the lithium ions is more effective than the insertion of $\mathrm{Li}^{+}$ ions in the structure of $\mathrm{V}_{2} \mathrm{O}_{5}$. On the $100^{\text {th }}$ cycle the coulombic efficiency was 0.98 indicating that the oxidation charge is practically balanced with the reduction. Therefore, with every cycle, there was stabilization in the flow of $\mathrm{Li}^{+}$ions in the material in order that in this cycle the insertion and de-insertion of $\mathrm{Li}^{+}$ions are practically the same.

Table 2 shows some important electrochromic parameters in scientific literature. In comparing this data with the ones obtained for vanadium oxide in this study, we can see that the electrochromic efficiency values found here are higher than the ones found in literature. In relation to the response times and transmittance variation, the values obtained are comparable, and in some cases even better than the ones found in literature.

Table 2. Comparison of electrochromic efficiency values, response times, transmittance variation and wavelengths found in literature to the ones found in this study

\begin{tabular}{|c|c|c|c|c|}
\hline $\begin{array}{c}n \\
\left(\mathrm{~cm}^{2} \mathrm{C}^{-1}\right)\end{array}$ & $\begin{array}{c}\text { Response time } \\
\text { (s) }\end{array}$ & $\begin{array}{l}\Delta T \\
(\%)\end{array}$ & $\begin{array}{c}\text { Wavelength } \\
\mathrm{nm}\end{array}$ & Literature \\
\hline$\sim 55$ & $\sim 3.5 \mathrm{e} \sim 1$ & 45 & 410 & This work \\
\hline 14 & 2 & ----- & 800 & Nagase et al. ${ }^{51}$ \\
\hline ------ & 6 e 5 & 37,4 & 415 & Cheng et $a l^{52}$ \\
\hline 13 & ------- & ------- & 630 & Patil et $a .^{53}$ \\
\hline 33.7 & ------ & 36,5 & 400 & Lin et $a .^{54}$ \\
\hline ------ & 6 e 1 & 60 & 633 & Xiong et $a l^{55}$ \\
\hline
\end{tabular}


This is due to the increase of specific superficial area, which reduces significantly the diffusion pathway of the $\mathrm{Li}^{+}$ions, and simultaneously, the number of accessible intercalation sites. This effect improved kinetics transport for electrochemical intercalation.

\section{Conclusion}

The synthesized lamellar vanadium oxide through a combination of synthesis, melt quenching and sonochemistry presented an interllamelar spacing of $13.3 \AA$. Its composition was estimated by TGA, which showed that the structure of the xerogel oxide was $\mathrm{V}_{2} \mathrm{O}_{5} \cdot 1 \cdot 8 \mathrm{H}_{2} \mathrm{O}$. The FESEM images proved the presence of a fibrous structure comprised by agglomerates of fibers of $\mathrm{V}_{2} \mathrm{O}_{5}$ with lengths varying from 140 to $160 \mathrm{~nm}$, and diameters varying from 10 to $15 \mathrm{~nm}$. The hydrated vanadium oxide was also characterized by FT-IR and EPR which proved its synthesis. The use of this oxide in electrochromic electrodes, through spectroelectrochemical measurements in situ showed a transmittance variation of $45 \%$ in a wavelength of $(410 \mathrm{~nm})$ maintaining color at around $91.3 \%$ after 100 cycles; response times for the oxidation and reduction were below 3.5 seconds, electrochromic efficiency of approximately $55 \mathrm{~cm}^{2} \mathrm{C}^{-1}$ at $410 \mathrm{~nm}$ throughout the 100 cycles of color change among blue-green-orange. The values of coulombic efficiency indicated that within each cycle there was a stabilization of the material in order that in the $100^{\text {th }}$ cycle the insertion and de-insertion of $\mathrm{Li}^{+}$ions are practically the same. All of the verified electrochromic parameters showed that this oxide has great potential for the application in electrochromic electrodes.

\section{Acknowledgments}

The authors would like to thank the grant agencies Capes, CNPq, PROPPI-UFF, PROPPUFMS and Faperj (E-26-102.971/2012 and E$26 / 111.407 / 2013$ ) for the financial support. The Brazilian Center for Physical Research (CBPF) for the use of the EPR spectrometer. The authors also thank the LDRX-UFF X-ray diffraction laboratory for the data collection.

\section{References}

${ }^{1}$ Donnadieu, A. Electrochromic materials. Materials Science and Engineering: B 1989, 3, 185. [CrossRef]

2 Oliveira, R. S.; Semaan, F. S; Ponzio, E. A. Janelas Eletrocrômicas: Uma Nova Era em Eficiência Energética. Revista Virtual de Química 2015, 7, 336. [CrossRef]

${ }^{3}$ Oliveira, M. R. S.; Mello, D. A. A.; Oliveira, R. S.; Ponzio, E. A.; Oliveira, S. C. In Advances in Nanotechnology; Bartul, Z.; Trenor, J., eds.; Nova Publishers: New York, 2011, Vol 8, cap. 1. [Link]

${ }^{4}$ Monk, P. M. S.; Mortimer, R. J.; Rosseinsky, D. R. In Electrochromism: Principles and Applications; Bernd Speiser, ed.; VCH Verlagsgesellschaft: Weinheim, 1995; Vol 108, cap. 3. [CrossRef]

${ }^{5}$ Granqvist, C. G.; Niklasson, G. A.; Azens, A. Electrochromics: Fundamentals and energyrelated applications of oxide-based device. Applied Physics A 2007, 89, 29. [CrossRef]

${ }^{6}$ Granqvist, C. G.; Azens, A.; Smulko, J.; Kish, L. B. Oxide-based electrochromics for energy efficient buildings: materials, technologies, testing, and perspectives. Journal of Physics: Conference Series 2007, 93, 012021. [CrossRef]

7 Ponzio, E. A.; Benedetti, T. M.; Torresi, R. M. Electrochemical and morphological stabilization of $\mathrm{V}_{2} \mathrm{O}_{5}$ nanofibers by the 
addition of polyaniline. Electrochimica Acta 2007, 52, 4419. [CrossRef]

${ }^{8}$ Livage, J. Sol-gel chemistry and electrochemical properties of vanadium oxide gels. Solid State lonics 1996, 86-88, 935. [CrossRef]

${ }^{9}$ Granqvist, C. G.; Green, S.; Niklasson, G. A.; Mlyuka, N. R.; von Kraemer, S.; Georen, P. Advances in chromogenic materials and devices. Thin Solid Films 2010, 518, 3046. [CrossRef]

${ }^{10}$ Granqvist, C. G.; Lansaker, P. C.; Mlyuka, N. R.; Niklasson, G. A.; Avendano, E. Progress in chromogenics: New results for electrochromic and thermochromic materials and devices. Solar Energy Materials and Solar Cells 2009, 93, 2032. [CrossRef]

${ }^{11}$ Scarminio, J.; Talledo, A.; Andersson, A. A.; Passerini, S.; Decker, F. Stress and electrochromism induced by $\mathrm{Li}$ insertion in crystalline and amorphous $\mathrm{V}_{2} \mathrm{O}_{5}$ thin film electrodes. Electrochimica Acta 1993, 38, 1637. [CrossRef]

${ }^{12}$ Pyun, S.-I.; Bae, J.-S. Electrochemical lithium intercalation into vanadium pentoxide xerogel film electrode. Journal of Power Sources 1997, 68, 669. [CrossRef]

${ }^{13}$ Zakharova, G. S.; Volkov, V. L. Intercalation compounds based on vanadium(V) oxide xerogel. Russian Chemical Reviews 2003, 72, 311. [CrossRef]

${ }^{14}$ Kang, S.-G.; Kim, K. M.; Park, N.-G.; Ryu, K. S.; Chang, S.-H. Factors affecting the electrochemical performance of organic $/ \mathrm{V}_{2} \mathrm{O}_{5}$ hybrid cathode materials. Journal of Power Sources 2004, 133, 263. [CrossRef]

${ }^{15}$ Benmoussa, M.; Outzourhit, A.; Bennouna, A.; Ihlal, A. $\mathrm{Li}^{+}$ions diffusion into sol-gel $\mathrm{V}_{2} \mathrm{O}_{5}$ thin films: electrochromic properties. European Physical Journal: Applied Physics 2009, 48, 10502. [CrossRef]

${ }^{16}$ Patil, C. E.; Jadhav, P. R.; Tarwal, N. L.; Deshmukh, H. P.; Karanjkar, M. M.; Patil, P. S. Electrochromic performance of mixed $\mathrm{V}_{2} \mathrm{O}_{5}$ $\mathrm{MoO}_{3}$ thin films synthesized by pulsed spray pyrolysis technique. Materials Chemistry and Physics 2011, 126, 711. [CrossRef]

${ }^{17}$ Zou, C. W.; Yan, X. D.; Chen, R. Q.; Wu, Z. Y.; Alyamani, A.; Gao, W. Effect of annealing on the microstructure and optical properties of $\mathrm{ZnO} / \mathrm{V}_{2} \mathrm{O}_{5}$ composite. Applied Physics Letters 2011, 98, 111904. [CrossRef]

18 lida, Y.; Kaneko, Y.; Kanno, Y. Fabrication of pulsed-laser deposited $\mathrm{V}_{2} \mathrm{O}_{5}$ thin films for electrochromic devices. Journal of Materials Processing Technology 2008, 197, 261. [CrossRef]

${ }^{19}$ Nandakumar, N. K.; Seebauer, E. G. Low temperature chemical vapor deposition of nanocrystalline $\mathrm{V}_{2} \mathrm{O}_{5}$ thin films. Thin Solid Films 2011, 519, 3663. [CrossRef]

${ }^{20}$ Yu, D.; Chen, C.; Xie, S.; Liu, Y.; Park, K.; Zhou, X.; Zhang, Q.; Li, J.; Cao, G. Mesoporous vanadium pentoxide nanofibers with significantly enhanced Li-ion storage properties by electrospinning. Energy \& Environmental Science 2011, 4, 858. [CrossRef]

${ }^{21}$ Mao, C.-J.; Pan, H.-C.; Wu, X.-C.; Zhu, J.-J.; Chen, H.-Y. Sonochemical Route for SelfAssembled $\mathrm{V}_{2} \mathrm{O}_{5}$ Bundles with Spindle-like Morphology and Their Novel Application in Serum Albumin Sensing. The Journal of Physical Chemistry B 2006, 110, 14709. [CrossRef]

${ }^{22}$ Zhang, Y.; Hu, X.; Liu, Y.; Gu, Q.; Cheng, Y. Process Parameters of $\mathrm{A}-\mathrm{V}_{2} \mathrm{O}_{5}$ Prepared by melt-quenching method. Electrochemical and Solid-State Letters 2005, 8, A646. [CrossRef]

${ }^{23}$ Collinson, M. M. Sol-Gel Strategies for the preparation of selective materials for chemical analysis. Critical Reviews in Analytical Chemistry 1999, 29, 289. [CrossRef]

${ }^{24}$ Taufiq-Yap, Y. H.; Wong, Y. C.; Zainal, Z.; Hussein, M. Z. Synthesis of self-assembled nanorod vanadium oxide bundles by sonochemical treatment. Journal of Natural Gas Chemistry 2009, 18, 312. [CrossRef]

${ }^{25}$ Mao, C.-J.; Pan, H.-C.; Wu, X.-C.; Zhu, J.-J.; Chen, H.-Y. Sonochemical Route for SelfAssembled $\mathrm{V}_{2} \mathrm{O}_{5}$ Bundles with Spindle-like 
Morphology and Their Novel Application in Serum Albumin Sensing. The Journal of Physical Chemistry B 2006, 110, 14709. [CrossRef]

${ }^{26}$ Gedanken, A. Using sonochemistry for the fabrication of nanomaterials. Ultrasonics Sonochemistry 2004, 11, 47. [CrossRef]

${ }^{27}$ Bang, J. H.; Suslick, K. S. Applications of Ultrasound to the Synthesis of Nanostructured Materials. Advanced Materials 2010, 22, 1039. [CrossRef]

${ }^{28}$ Zhang, Y.; Lin, S.; Fang, Y. New developments in sonochemistry, preparation of nanomaterials by ultrasound. Chinese Physics Letters 2002, 31, 80. [Link]

${ }^{29}$ Ohayon, E.; Gedanken, A. The application of ultrasound radiation to the synthesis of nanocrystalline metal oxide in a non-aqueous solvent. Ultrasonics Sonochemistry 2010, 17, 173. [CrossRef]

${ }^{30}$ Adhikary, K.; Kikkawa, S. Preparation and electrochemical lithium intercalation of $\mathrm{V}_{2} \mathrm{O}_{5}$ porous lump with large surface area1. Solid State Ionics 1997, 99, 53. [CrossRef]

${ }^{31}$ Nabavi, M.; Sanchez, C.; Taulelle, F.; Livage, J.; Guibert, A. Electrochemical properties of amorphous $\mathrm{V}_{2} \mathrm{O}_{5}$. Solid State lonics 1988, 2830, 1183. [CrossRef]

${ }^{32}$ Livage, J.; Collongues, R. Semiconducting properties of amorphous $\mathrm{V}_{2} \mathrm{O}_{5}$ prepared by splat cooling. Materials Science and Engineering 1976, 23, 297. [CrossRef]

${ }^{33}$ Livage, J.; Gharbi, N.; Leroy, M. C.; Michaud, M. Hydratation et texture fibreuse de $\mathrm{V}_{2} \mathrm{O}_{5}$ amorphe. Materials Research Bulletin 1978, 13, 1117. [CrossRef]

${ }^{34}$ Cocciantelli, J. M.; Ménétrier, M.; Delmas, C.; Doumerc, J. P.; Pouchard, M.; Broussely, M.; Labat, J. On the $\delta \rightarrow \gamma$ irreversible transformation in $\mathrm{Li} / / \mathrm{V}_{2} \mathrm{O}_{5}$ secondary batteries. Solid State lonics 1995, 78, 143. [CrossRef]

${ }^{35}$ de Oliveira, R. S.; da S. Goulart, J.; Miranda, F. S.; Ponzio, E. A. Melt sonoquenching: an affective process to obtain new hybrid material and achieve enhanced electrochromic performances based on $\mathrm{V}_{2} \mathrm{O}_{5}$ /2,4,5-tris(1-methyl-4-pyridinium)-

imidazolide tetrafluoroborate nanofibers. Journal of the Brazilian Chemical Society 2014, 25, 540. [CrossRef]

${ }^{36}$ Klima, J. Application of ultrasound in electrochemistry. An overview of mechanisms and design of experimental arrangement. Ultrasonics 2011, 51, 202. [CrossRef]

${ }^{37}$ Oliveira, H. P.; Graeff, C. F. O.; Rosolen, J. $M$. Synthesis and structural characterization of tetrakis(n-methyl-4-pyridyl) porphyrin copper into $\mathrm{V}_{2} \mathrm{O}_{5}$ xerogel. Materials Research Bulletin 1999, 34, 1891. [CrossRef]

${ }^{38}$ Baddour, R.; Pereira-Ramos, J. P.; Messina, R.; Perichon, J. A thermodynamic, structural and kinetic study of the electrochemical lithium intercalation into the xerogel $\mathrm{V}_{2} \mathrm{O}_{5} \cdot 1.6$ $\mathrm{H}_{2} \mathrm{O}$ in a propylene. Journal of Electroanalytical Chemistry and Interfacial Electrochemistry 1991, 314, 81. [CrossRef]

${ }^{39}$ Shimizu, A.; Tsumura, T.; Inagaki, M. Electrochemical intercalation of lithium into $\mathrm{V}_{2} \mathrm{O}_{5}$ : Effect of host materials. Solid State lonics 1993, 63-65, 479. [CrossRef]

${ }^{40}$ Murphy, D. W.; Christian, P. A.; DiSalvo, F. J.; Carides, J. N.; Waszczak, J. V. Lithium incorporation by $\mathrm{V}_{6} \mathrm{O}_{13}$ and related vanadium $(+4,+5)$ oxide cathode materials. Journal of The Electrochemical Society 1981, 128, 2053. [CrossRef]

${ }^{41}$ Dickens, P. G.; Reynolds, G. J. Transport and equilibrium properties of some oxide insertion compounds. Solid State lonics 1981, 5, 331. [CrossRef]

${ }^{42}$ Gharbi, N.; R'Kha, C.; Ballutaud, D.; Michaud, M.; Livage, J.; Audiere, J. P.; Schiffmacher, G. A new vanadium pentoxide amorphous phase. Journal of Non-Crystalline Solids 1981, 46, 247. [CrossRef]

${ }^{43}$ Takiyama, K. Formation and Aging of Precipitates. VI. Morphology of Crystals in Various Vanadium Pentoxide Sols by Electron Microscopy. Bulletin of the Chemical Society of Japan 1958, 31, 329. [CrossRef] 
${ }^{44}$ Somani, P. R.; Marimuthu, R.; Mandale, A. B. Synthesis, characterization and charge transport mechanism in conducting polyaniline $/ \mathrm{V}_{2} \mathrm{O}_{5}$ composites. Polymer 2001, 42, 2991. [CrossRef]

${ }^{45}$ Narayana, K. V.; Raju, B. D.; Masthan, S. K.; Rao, V. V.; Rao, P. K.; Subrahmanian, R.; Martin, A. ESR spectroscopic characterization of $\mathrm{V}_{2} \mathrm{O}_{5} / \mathrm{AlF}_{3}$ ammoxidation catalysts. Catalysis Communications 2004, 5, 457. [CrossRef]

${ }^{46}$ Nascimento, O. R.; Magon, C. J.; Lima, J. F.; Donoso, J. P.; Benavente, E.; Paez, J.; Lavayen, V.; Santa, A. M. A.; Gonzalez, G. Magnetic resonance study of a vanadium pentoxide gel. Journal of Sol-Gel Science and Technology 2008, 45, 195. [CrossRef]

${ }^{47}$ Stoll, S.; Schweiger, A. EasySpin, a comprehensive software package for spectral simulation and analysis in EPR. Journal of Magnetic Resonance 2006, 178, 42. [CrossRef]

${ }^{48}$ Ryczkowsky, J. IR spectroscopy in catalysis. Catalysis Today 2001, 68 263. [CrossRef]

${ }^{49}$ Liu, J.; Zhao, Z.; Xu, C.; Duan, A.; Zhu, L.; Wang, $\mathrm{X}$. The structures of $V \mathrm{VO}_{\mathrm{x}} / \mathrm{MO}_{\mathrm{x}}$ and alkali- $\mathrm{VO}_{\mathrm{x}} / \mathrm{MO}_{\mathrm{x}}$ catalysts and their catalytic performances for soot combustion. Catalysis Today 2006, 118, 315. [CrossRef]

${ }^{50}$ Chary, K. V. R.; Kumar, C. P.; Naresh, D.; Bhaskar, T.; Sakata, Y. Characterization and reactivity of $\mathrm{Al}_{2} \mathrm{O}_{3}-\mathrm{ZrO}_{2}$ supported vanadium oxide catalysts. Journal of Molecular Catalysis A: Chemical 2006, 243, 149. [CrossRef]

${ }^{51}$ Vidotti, M.; Torresi, R. M.; Torresi, S.I.C. Eletrodos modificados por hidróxido de níquel: um estudo de revisão sobre suas propriedades estruturais e eletroquímicas visando suas aplicações em eletrocatálise, eletrocromismo e baterias secundárias. Química Nova 2010, 33, 2176. [CrossRef]

52 Nagase, K.; Shimizu, Y.; Miura, N.; Yamazoe, N. Electrochromic properties of vanadium pentoxide thin films prepared by new wet process. Applied Physics Letters 1992, 60, 802. [CrossRef]

${ }^{53}$ Cheng, K.-C.; Chen, F.-R.; Kai, J.-J. $\mathrm{V}_{2} \mathrm{O}_{5}$ nanowires as a functional material for electrochromic device. Solar Energy Materials and Solar Cells 2006, 90, 1156. [CrossRef]

${ }^{54}$ Patil, C. E.; Tarwal, N. L.; Shinde, P. S.; Deshmukh, H. P.; Patil, P. S. Synthesis of electrochromic vanadium oxide by pulsed spray pyrolysis technique and its properties. Journal of Physics D: Applied Physics 2009, 42, 1. [CrossRef]

${ }^{55}$ Lin, Y.-S.; Tsai, C.-W. Reactive sputtering deposition of $\mathrm{V}_{2} \mathrm{O}_{5-z}$ on flexible PET/ITO substrates for electrochromic devices. Surface and Coatings Technology 2008, 202, 5641. [CrossRef] 